Bentham open
CrossMark

\title{
Catheter Related Escherichia hermannii Sepsis in a Haemodialysis Patient
}

\author{
Cecilie Utke Rank ${ }^{1, *}$, Peter Lommer Kristensen ${ }^{1}$, Dennis Schrøder Hansen ${ }^{2}$ and Lisbet Brandi ${ }^{1}$ \\ ${ }^{1}$ Department of Cardiology, Nephrology, and Endocrinology, Nordsjoellands Hospital, Hillerød, Denmark \\ ${ }^{2}$ Department of Clinical Microbiology, Herlev and Gentofte Hospital, University Hospital of Copenhagen, Denmark
}

\begin{abstract}
Escherichia hermannii is an extremely rare etiological agent of invasive infection, and thus, the bacterium was initially considered non-pathogenic. However, in five previously reported case reports E. hermannii has been implicated as the sole pathogen. Our case report describes blood stream infection with E.hermannii in a haemodialysis patient with persisting symptoms, high fever and inflammatory markers despite appropriate antibiotic treatment until replacement of the dialysis catheter. We suspect biofilm formation to be a crucial pathogenic feature for E. hermannii in the maintenance of an infection, which stresses the necessity of antibiotic treatment along with catheter replacement in bloodstream- and catheter-related infection with E. hermannii.
\end{abstract}

Keywords: Biofilm, Escherichia hermannii, gram-negative bacterial infections, haemodialysis, tunnelled catheter infection.

\section{INTRODUCTION}

Escherichia hermannii is part of the bacilli family Enterobacteriaceae and was initially described as an E. coli-like biogroup. In 1982 Brenner et al. proposed E. hermannii as a distinct new species within the genus Escherichia based on DNA relatedness and phenotypic data. Primarily, the bacterium has been found in environmental sources, wounds, sputum, and stool - and was initially considered to be non-pathogenic [1, 2]. However, in five previously reported case reports comprising six patients, E. hermannii was the sole pathogen found; in purulent conjunctivitis, an infected cephalohematoma, two catheter-related bloodstream infections, sepsis, and pyelonephritis, respectively [3 - 8].

\section{Case history}

A 65-year-old male was admitted with fever, chills and sweating after a regular haemodialysis session. Furthermore, he had a 3-day history of diarrhoea. His medical record included dialysis-dependent end-stage renal disease, secondary to hypertensive nephropathy, and arthritis urica. Haemodialysis with a tunnelled haemodialysis catheter had been initiated 3 months earlier due to recurrent peritonitis during peritoneal dialysis. The tunnelled catheter was used as a temporary dialysis access until transition to an arteriovenous fistula, which had been inserted a couple of days prior to hospitalization. Due to arthritis urica, the patient was treated with prednisolone $25 \mathrm{mg}$ once daily.

Physical examination did not reveal signs of localized infection. Vital signs on admission were heart rate 116/min, blood pressure $189 / 101 \mathrm{mmHg}$, respiratory rate $16 / \mathrm{min}$, saturation $95 \%\left(1 \mathrm{~L} \mathrm{O}_{2}\right)$, and temperature $41.8^{\circ} \mathrm{C}$. Laboratory testing showed white blood cell count of $5.9 \times 10^{9} / \mathrm{L}$ (on day $5: 9 \times 10^{9} / \mathrm{L}$ ) with $79 \%$ neutrophils, C-reactive protein (CRP) of $31 \mathrm{mg} / \mathrm{L}$ (on day $5: 118 \mathrm{mg} / \mathrm{L}$ ), haemoglobin $6.3 \mathrm{mmol} / \mathrm{L}$, and blood platelets $156 \times 10^{9} / \mathrm{L}$. Urine analysis and stool cultures were unremarkable. The initial tentative diagnosis was sepsis due to diverticulitis - however, a computed tomography scan of abdomen did not reveal any site of infection.

The empirical treatment was piperacillin-tazobactam 8 gram once daily intravenously (IV). In total 8 of 8 blood

\footnotetext{
* Address correspondence to this author at the Nordsjællands Hospital, Hillerød, Dyrehavevej 29, 3400 Hillerød, Denmark; Tel: +45 26858297 ; E-mail: cecilieutkerank@gmail.com
} 
culture bottles collected peripherally and from the tunnelled catheter and culture from the removed catheter tip grew Gram-negative rods - thus, IV metronidazole $1.5 \mathrm{gm}$ once daily was added to the treatment. The culture was identified as E. hermannii, and the isolate was found resistant to ampicillin but sensitive to mecillinam, cefuroxime, ceftazidime, meropenem, gentamicin, piperacillin-tazobactam and ciprofloxacin. On day 4 of hospitalization the patient evolved fever $\left(42^{\circ} \mathrm{C}\right)$ and chills during haemodialysis. On day 6 , the tunnelled catheter was replaced due to suspicion of biofilm formation. Thereafter, the patient experienced improvement in symptoms, lysis of fever, and decrease in CRP. The patient was discharged on day 8 and completed a 2-week antibiotic course with oral mecillinam. The patient has been followed up for 6 months, has been subscribed to ScandiaTransplant waiting list and is doing well.

\section{METHODS}

Blood culture was performed using BacT/ALERT SA (aerobic) and BacT/ALERT SN (anaerobic) bottles incubated in the BacT/Alert 3D blood culture instrument (bioMérieux, Ballerup, Denmark). Positive blood cultures were Gram stained and inoculated on 5\% horse blood agar plates and on modified Conradi Drigalski agar plates and incubated o/n. Colonies were identified by MALDI-TOF as E. hermannii with a logscore of 2.4 using a Microflex LT (Bruker Daltonics) with database version MBT-DB-56275. Susceptibility testing was performed by disc diffusion using Oxoid disc and interpreted using EUCAST breakpoints (http://www.eucast.org). Identification was verified by partial sequencing of $468 \mathrm{nt}$ of the $16 \mathrm{~S}$ rRNA gene, showing $100 \%$ similarity to E. hermannii type strain CIP 103176 (NR 104940.2). In short, PCR for the 16S rRNA gene was performed as described by Wilmotte et al. 1983 with some modifications (Wilmotte et al. 1993, FEBS, vol 317, s. 96-100). DNA was extracted from a fresh bacterial culture using the EasyMag Nuclisense system (Biomeriéux, Ballerup Denmark). In regard to PCR amplification we used the Thermo Scientific Fusion HF polymerase and a Bioer LifePro Termocycler, with the following amplification profile; $98^{\circ} \mathrm{C}$ for $30 \mathrm{~s}$, followed by 25 cycles at $98^{\circ} \mathrm{C}$ for $10 \mathrm{~s}, 53^{\circ} \mathrm{C}$ for $20 \mathrm{~s}$, and $72^{\circ} \mathrm{C}$ for $30 \mathrm{~s}$, and final extension at $72^{\circ} \mathrm{C}$ for $5 \mathrm{~min}$. Presence of a PCR product was verified using the QIAxcel capillary gel electrophoresis system (Qiagen, Copenhagen, Denmark). The PCR product was purified using the Qiagen MinElute PCR-purification kit before it was sequenced at Macrogene ${ }^{\circledR}$ (Macrogene, Amsterdam, Netherland). Forward and reverse sequences were aligned and visually checked using MicroSeq v. 2.1.1. Finally, the edited consensus sequence was used to query the NCBI bacterial database using BLASTn (http://blast.ncbi.nlm.nih.gov) for the species identification.

\section{RESULTS AND DISCUSSION}

Initially, E. hermannii was considered non-pathogenic - but this case reported along with previously reported cases shows that it might be a pathogen. E. hermannii is an extremely rare etiological agent for invasive infections, and the bacterium is primarily an opportunistic pathogen, which causes disease in immunocompromised hosts or through use of a central catheter, as in the present case. Yamanaka et al. suggests that contributing factors to pathogenicity are the ability to produce mannose-rich exopolysaccharides and to form meshwork-like structures. Exopolysaccharide production and the presence of cell surface-associated meshwork-like structures are some of the common features associated with biofilm-forming bacteria [9].

To our knowledge, only 3 other case reports with E. hermannii causing bloodstream infection are reported. In the current case report we suspect biofilm formation to be a crucial pathogenic feature for E. hermannii, because of the lack of clinical improvement until removal of the dialysis catheter. However, biofilm formation and its potential role in infections with E. hermannii still have to be confirmed in other studies. Furthermore, E. hermannii has a natural resistance to penicillin, ampicillin, and carbenicillin because of its $\beta$-lactamase production - which complicates treatment [10]. Currently, there is insufficient clinical data on the optimal antibiotic treatment - but mostly various $\beta$ lactams and quinolones with in vivo susceptibility have been used.

\section{CONFLICT OF INTEREST}

The authors confirm that this article content has no conflict of interest.

\section{ACKNOWLEDGEMENTS}

Declared none.

\section{REFERENCES}


Escherichia hermannii sp. nov. J Clin Microbiol 1982; 15(4): 703-13.

[PMID: 7040466]

[2] Rice EW, Sowers EG, Johnson CH, Dunnigan ME, Strockbine NA, Edberg SC. Serological cross-reactions between Escherichia coli O157 and other species of the genus Escherichia. J Clin Microbiol 1992; 30(5): 1315-6. [PMID: 1583138]

[3] Poulou A, Dimitroulia E, Markou F, Tsakris A. Escherichia hermannii as the sole isolate from a patient with purulent conjunctivitis. J Clin Microbiol 2008; 46(11): 3848-9.

[http://dx.doi.org/10.1128/JCM.01119-08] [PMID: 18768650]

[4] Dahl KM, Barry J, DeBiasi RL. Escherichia hermannii infection of a cephalohematoma: case report, review of the literature, and description of a novel invasive pathogen. Clin Infect Dis 2002; 35(9): e96-8.

[http://dx.doi.org/10.1086/342304] [PMID: 12384853]

[5] Kaewpoowat Q, Permpalung N, Sentochnik DE. Emerging Escherichia pathogen. J Clin Microbiol 2013; 51(8): $2785-6$. [http://dx.doi.org/10.1128/JCM.00983-13] [PMID: 23740732]

[6] Tong YQ, Xin B, Sun SQ. Pyelonephritis caused solely by Escherichia hermanii. Jundishapur J Microbiol 2014; 7(5): e18138. [http://dx.doi.org/10.5812/jjm.18138] [PMID: 25147714]

[7] Choudhury S, Seet C. Escherichia hermannii bloodstream infection in a long-term haemodialysis patient. Pathology 2013; $45(5)$ : 531. [http://dx.doi.org/10.1097/PAT.0b013e3283633fd7] [PMID: 23856851]

[8] Ginsberg HG, Daum RS. Escherichia hermannii sepsis with duodenal perforation in a neonate. Pediatr Infect Dis J 1987; 6(3): 300-2. [http://dx.doi.org/10.1097/00006454-198703000-00025] [PMID: 3575017]

[9] Yamanaka T, Sumita-Sasazaki Y, Sugimori C, et al. Biofilm-like structures and pathogenicity of Escherichia hermannii YS-11, a clinical isolate from a persistent apical periodontitis lesion. FEMS Immunol Med Microbiol 2010; 59(3): 456-65.

[PMID: 20553325]

[10] Beauchef-Havard A, Arlet G, Gautier V, Labia R, Grimont P, Philippon A. Molecular and biochemical characterization of a novel class A beta-lactamase (HER-1) from Escherichia hermannii. Antimicrob Agents Chemother 2003; 47(8): 2669-73. [http://dx.doi.org/10.1128/AAC.47.8.2669-2673.2003] [PMID: 12878539]

Received: April 22, 2015 Revised: July 23, 2015

Accepted: July 24, 2015

(C) Rank et al. ; Licensee Bentham Open.

This is an open access article licensed under the terms of the Creative Commons Attribution-Non-Commercial 4.0 International Public License (CC BY-NC 4.0) (https://creativecommons.org/licenses/by-nc/4.0/legalcode), which permits unrestricted, non-commercial use, distribution and reproduction in any medium, provided the work is properly cited. 